\title{
THE EFFECT OF PACKAGING, SATISFACTION AND IMAGE ON CUSTOMER LOYALTY OF THE EL RAYHAN COMPANY
}

\author{
Ahmed Khaled El Gammudi \\ Ubud Salim \\ Ananda Sabil \\ University of Brawijaya
}

\begin{abstract}
This study is aimed at investigating the effect of packaging, satisfaction, and image on customer loyalty to The El Rayhan Company, Libya. The questionnaires are employed to collect the data. The resultreveals that packaging has a positive effect on customer loyalty. Moreover, satisfaction and image affect directly on customer loyalty. However, the highest effect in this study is the packaging effect on customer loyalty.
\end{abstract}

Key words: Packaging, Satisfaction, Brand Image, and Customer Loyalty.

\section{INTRODUCTION}

Today most organizations face a number of fundamental challenges as the most important scientific and technological development, and the market increases in the number of institutions of different activities. In addition, the rapid and continuous changes of consumers' needs and tastes have become a major factor in strategic plans and marketing plans, and the cornerstone of modern marketing.

Companies throughout the nation are now utilizing loyalty programs more often than ever before. Theyunderstand the importance of retaining existing customers and decide to implement a system directed specifically to buildcustomer loyalty. A loyalty program is a marketing system instituted by a business that rewards purchasing behavior, thus it increases the customers' urge to stay loyal to the company. It may offer convenience, store credit, prizes, or any other benefits that would entice the loyalty of the customers. When some marketers think of loyalty programs, they begin to imagine a large portion of existing resources being funneled away into a program that may or may not find the success.

Packaging is one of the main strategies and policies that the productive institutions depends on. It represents the message that creates link between the product and the customers. In the way that the packing policy and packaging is vital to the success of marketing item, as an integral part of them often and one of the elements or the physical components. 
Today it can be noted that most of the food is packed in plastic bottles, glass or metal. In order to preserve the nature of food and specifications throughout the interval between the moment of manufacturing and packaging until the sale and consumption of locally or after export.

\section{Loyalty}

According to Walsh et al. (2008) Loyalty is defined as repeated purchase behavior led by favorable attitudes or as a consistent purchase behavior resulting from the psychological decision making. The loyalty is the relationship between the organization and producer with the consumer. Customer loyalty helps in building satisfaction and trust toward the service or products. When customers are loyal to product, there will be an assurance that these customers will support the products, as a result it increases the sales and avoids bankruptcy.

Oliver R (1997) mentioned that loyalty is a deeply held commitment to re-buy or re-patronize a preferred product or service consistently in the future, which causes repetitive same brand or same brand set purchasing, despite any situational influences and marketing efforts that might cause switching behavior.

Jacoby and Chestnut (1978) provided a conceptual definition of brand loyalty as: (i) biased (i.e. non-random), (ii) behavioral response (i.e. purchase), (iii) expressed over time, (iv) by some decision making unit, (v) with respect to one or more brands out of a set of such brands, and is a function of psychological (decision -making evaluation) processes.

Sheth and Mittal (2004) mentioned that Brand loyalty is a measure of the extent to which consumers are loyal to a particular brand over a period of time, which emphasizes a consistent repurchase of the same brand.

\section{Packaging}

Packaging is the technology of enclosing or protecting products for distribution, storage, sale, and use. There is an old saying that a package must protect what it sells and sell what it protects. It may be an old saying, but it is still true. A package functions as a "silent salesman" (Lockhart, 1995). Packaging has types which helps to distribute with protecting the product. There are four types of packaging:

1. A Primary Package. It is the type which is in direct contact with the contained product. It provides the initial and usually the major protective barrier. Examples of primary packages includes metal cans, glass bottles, and plastic pouches. It is frequently onlythe primary package which the consumer purchases at retail outlets.

2. A Secondary Package. It contains a number of primary packages, a corrugated case. It is the physical distribution carrier and is sometimes 
designed so that it can be used in retail outlets for the display of primary packages.

3. A Tertiary Package. It is made up of a number of secondary packages. The most common example is a stretch wrapped pallet of corrugated cases.

4. A Quaternary Package. It is frequently used tofacilitate the handling of tertiary packages in interstate and international trade. This is generally a metal container up to $12 \mathrm{~m}$ in length which can hold many pallets and is intermodal in nature. It means, it can be transferred to or from ships trains, and flatbed trucks by cranes. Certain designs are also able to have their temperature, humidity and gas atmosphere controlled and this is necessary in particular situations such as for the transportation of frozen foods or fresh fruits and vegetables.

Packaging has been defined in a number of ways. The Packaging Institute International defines packaging as the enclosure of products, items or packages in a wrapped pouch, bag, box, cup, tray, can, tube, bottle or other container form to perform one or more of the following functions, containment, protection or preservation, communications, and utility or performance. If the device or container performs one or more of these functions it is considered a package.

The UK Institute of Packaging provides three definitions of packaging:

1. A coordinated system of preparing goods for transport, distribution, storage, retailing and end use.

2. A means of ensuring safe delivery to the ultimate consumer in sound condition at minimum cost.

3. A techno economic function aimed at minimizing costs of delivery while maximizing sales and hence profits.

\section{Image}

Image can be defined as the set of beliefs, ideas, and impression that a person holds regarding an object.Furthermore, a brand can be defined as a name, term, sign, symbol, or design, or combination of them which is intended to identify the goods and services of one seller or group of sellers and to differentiate them from those of competitors (Kotler, 1991).Also, brand image has been recognized as an important concept in marketing (e.g., Gardner and Levy 1955). Consistent with definitions by Herzog (1963) and Newman (1957), brand image is defined here as perceptions about a brand as reflected by the brand associations held in consumer memory.

According to Hsiehetal. (2004), a successful brand image enables consumers to identify the needs that the brand satisfies and to differentiate the brand from its competitors, and consequently increases the likelihood that consumers will purchase the brand. 
On the other hand Keller (1993) considered brand image as a set of perceptions about a brand as reflected by brand associations in consumer's memory. A comparable explanation of Image to Keller's was proposed by Aker (1991) in which brand image is referred to a set of associations, usually organized in some meaningful way. However, Biel (1992) defined brand image as a cluster of attributes and associations that consumers connect to the brand name.

\section{Satisfaction}

Satisfaction is defined by saying it is the act of providing what is needed or desired, the act of satisfying a need or desire.Regarding with this study, satisfaction is a customer's feeling about a product or services applied by an organization or producer. Oliver(1997) defined satisfaction as the consumer's fulfillment response. It is a judgment that a product or service feature, or the product or service itself, provides (or is providing) a pleasurable level of consumption related fulfillment, including levels of under or over fulfillment. Szymanski and Henard (2001) noted that the previous study on consumer's satisfaction focused mostly on the effects of expectations, disconfirmation of expectations, performance, effect, and equity on satisfaction.In general, customer satisfaction is seen as an indicator of the future of financial success for the company (Kotler, 2000). The benefits of customer satisfaction are often associated with high customer loyalty, the more loyal the customers are, the more often they use the company's services or make purchases from the same supplier (Sasser and Jones, 1995). customer satisfaction can be described as the evaluation of a product or service taking place after a purchase considering the expectations the customer had before the purchase (Kotler, 2000).

\section{Research Framework}

H 1 :The packaging increasessatisfaction in El Rayhan company.

H 2 :The packaging increases loyalty in El Rayhan company.

H 3 :The packaging increases image in El Rayhan company.

$\mathrm{H} 4$ :The satisfaction increases loyalty in El Rayhancompany.

H 5 :The image increases loyalty in El Rayhan company. 


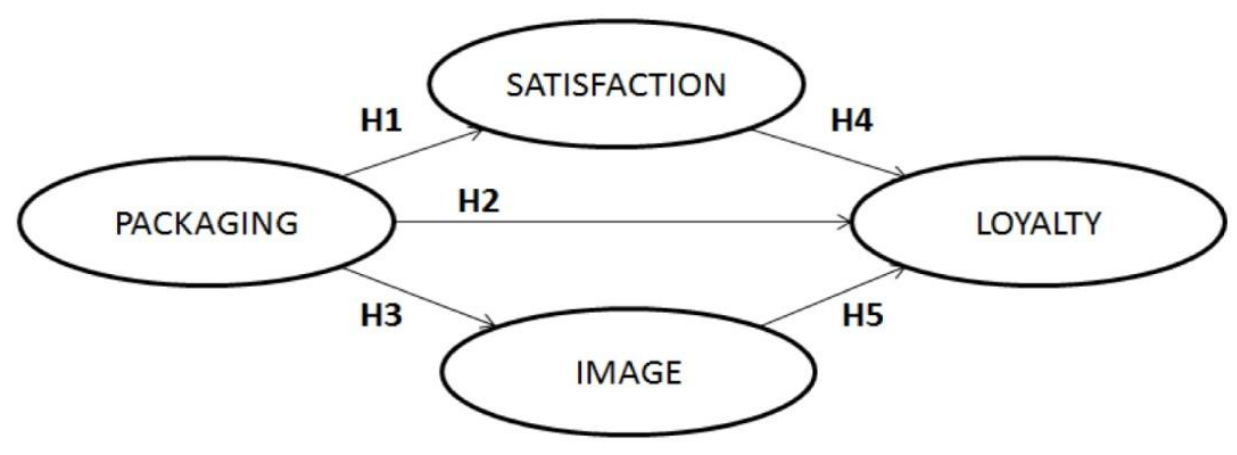

Figure 01: Research Framework

\section{Research Design}

This research uses quantitative approach, and considerably included in an explanatory research. Explanatory research is the one which is aimed at analyzing the relationships between variables or how one variable affects the other (Kotler, etal., 2006). This method is chosen because it is intended to access to the effect of packaging on customer loyalty and through this way the data are analyzed statistically. The location of the research is in Libya, a country where which The El Rayhan Company is located. The main product is juice drink. The respondentsof this study are all people who used to purchasingthe product.The instrument used in collecting data is a questionnaire. The selected data are analyzed by using PLS, defined as the method of choice to succeed factor studies in marketing (Albers, 2009). The PLS methodology have also achieved an increasingly popular mission in practical research in international marketing, which may represent an appreciation of distinctive methodological features of PLS.

\section{Discussion}

Through the results it becomes clear that the impact of packaging on customer loyalty is simple compared to other variables. Due to the different generations, there is a concern tothe consumersin experiencing and continuously consuming a new product.Note that those with the age group of 20-29 years arethe most responsive in completing the questionnaire. The nature of humanity is afraid of the unaware, in the sense that if the shape of the product development or product display is the same product with different form, the loyalty rate is remarkably decreased. 
As to the culture of the youth generations with age category ranging from less than 20 to 30 years old, they have a different concept of what is customary. It is because this age group is willing to maintain its loyalty to the product as long as the company keeps developingthe ways of packaging compared to other products. Moreover, it is also caused by the openness of the Libyan market to many juice companies from neighboring countries or even across the seas.

\section{Conclusion}

Based on the result of the research, it can be concluded as follows :

1. There is an effect of image on loyalty, it is explained that a better image of the costumers to El Rayhancompany increases their loyalty. That means the importance of image to loyalty.

2. There is an effect of packaging on image, it is explained that a better packaging of El Rayhancompany increases the image of the costumer. That means the importance of packaging to image.. In addition, there is a positive effect of packaging on the loyalty and satisfaction.

3. It shows that packaging, satisfaction, and image have a direct effecton loyalty.

4. Furthermore there is an effect of satisfaction on loyalty. It means that when costumers satisfy with El Rayhan product, it also increases their loyalty.

5. The result shows the importance of packaging on loyalty. Improving and designing a modern style of packaging affects customer loyalty. 


\section{REFERENCES}

Aaker, D. A. (1991). Managing brand equity. Capitalizing on the value of a brand name. New York: The Free Press.

Ahsan, B. J., \& Abdul, B. R. (2014). Impact of Customer Satisfaction, Brand Image and Advertisements on Brand Loyalty. European Journal of Business and Management , 49-56.

Akabogu, C. O. (2014). Consumers' Satisfaction with 7 up Packaging: an empirical Analysis . Journal of Business and Management , 28-36.

Albers, S.2009. Misleading Rankings of Research in Business German Economy Review. Germany.

Bennet, R., \& Rundle -Thiele, S. (2004). customer sattisfaction should not be the only goal. journal of service marketing, 514-523.

Biel, A. L. (1992). How brand image drives brand equity. Journal of Advertising Research , 6-12.

Camille, R. (2005). an Analysis of Relationship Marketing as an Effective Marketing Technique for Quick-Service Restaurants. International Journal of Contemporary Hospitality Management (Vol,17 No,7), 592.

Dey , Ian.1993 Qualitative data analysis . Routledge.

Dwayne, G., \& Stephen, B. (1996). Service Loyalty: Its Nature, Importance, and Implications. ISQA, 171-180.

el-rayhan.com. (2014). www.el-rayhan.com. Retrieved from el-rayhan.com.

Fecikova, I. (2004). An index method for measurement of customer satisfaction. the TQM magazine, 57-66.

Falk R. F. \& Miller, N. B.( 1992). A Primer for Soft Modeling. Akron, Ohio:The University of Akron Press.

Field, A. (2005). Discovering statistics using SPSS (Vol. 2nd). london: saga.

Hair, .. a. (1998). multivariate data analysis (Vol. 5th edition). new jersey: upper saldle river.

Hsieh, M., Pan, S., \& Setiono, R. (2004). Product-, corporate-, and countryimage dimensions and purchase behavior: A multicountry analy. Journal of the Academy of Marketing Science, 251-270.

Hysen, B., \& Mensur, V. (2008). ANALYSIS OF CONSUMER BEHAVIOUR IN REGARD TO DAIRY PRODUCTS IN KOSOVO. Agricultural Research, 111-126.

J.A. Wegelin. 2000 . A survey of Partial Least Squares (PLS) methods. with emphasis on the two-block case. Technical report, Department of statistic, Univercity of Washington, seattle

Jacoby, J., \& Chestnut, R. (1978). Brand loyalty: Measurement and management. New York: Wiley.

Josée, B., Ko, R. d., \& Pascal, P. (1998). Investigating drivers of bank loyalty: the complex relationship between image, service quality and satisfaction. International Journal of , 276-286.

Keller, K. L. (1993). Conceptualizing, measuring, and managing customerbased brand equity. Journal of Marketing, 1-22. 
Kotler, P. (2000). Marketing Management. The Millennium Edition. Prentice Hall International.

LO, L. K., Osman, M., T, R., \& Rahim, M. (2010). The Impact of Service Quality on Customer Loyalty: A Study of Banks in Penang, Malaysia. International Journal of Marketing Studies , 57-66.

Lockhart, H. (1995). A paradigm for packaging. Packaging education news , 25.

Manilall Dhurup, M. C., \& Dumasi, T. (2014). The impact of packaging, price and brand awareness on brand loyalty. Acta Commercii , 1-9.

McCarthy, D. G. (1997). The Loyalty Link: How Loyal Employees Create Loyal Customers. New York: Wiley and sons Inc.

Naresh K Malhotra, David F Birks.2007. 3rd eddition. MarketingResearch. An Applied Orientation. Harlow, Financial Times.

Oliver, R. L. (1997). Satisfaction: A behavioral perspective on the consumer. New york: Irwin/McGraw-Hill.

Pirouz, Dante, M. (2006). An Overview of Partial Least Squares. The Paul MerageSchool of Business University of California.

Peter, C. (2002). How Come Your Brand isn't Working Hard Enough? london: Kogan Page.

Rundh, B. (2012). Linking packaging to marketing :how packaging is influencing the marketing strategy . britch food journal , 1560.

Sasser, E. W., \& Jones, T. O. (1995). Why satisfied customers defect. harvard business review , 88-99.

Shahin, A., Abandi, A. A., \& Moshref Javad, M. H. (2011). Analyzig the relationshop between customer satisfaction and loyalty in the software industry. international journal of business and social science , 129-136.

Shahin, A., Abandi, A. A., \& Moshref Javadi, M. H. (2011). Analyzing the Relationship between Customer Satisfaction and Loyalty in the Software Industry. International Journal of Business and Social Science, 129.

Sheth, N., \& Mittal, B. (2004). consumer behaviour, a managerial perspective . Oh: Thomson South-Western.

Silayoi, P., \& Speece, M. (2004). packaging and purchase decisions . Britch Food lournal , 607-628.

Stephen, L., Maznah, W., \& Nabsiah, W. (2007). THE EFFECT OF BRAND IMAGE ON OVERALL SATISFACTION AND LOYALTY INTENTION IN THE CONTEXT OF COLOR COSMETIC. Asian Academy of Management Journal , 83-107.

Walsh, G., Evanschitzky, H., \& Wunderlich, M. (2008). Identification and analysis of moderator variables : Investigating the customer satisfaction-loyalty link. European Journal of Marketing, 977-1004.

Yuping, L. (2007). The Long-Term Impact of Loyalty Programs on Consumer Purchase Behavior and Loyalty. Journal of Marketing , 19-35. 
Zeithaml, Valarie A., Leonard L. Berry, and A. Parasuraman (1996). The Behavioral Consequences of Service Quality. Journal of Marketing, 60 (2), 31-46 